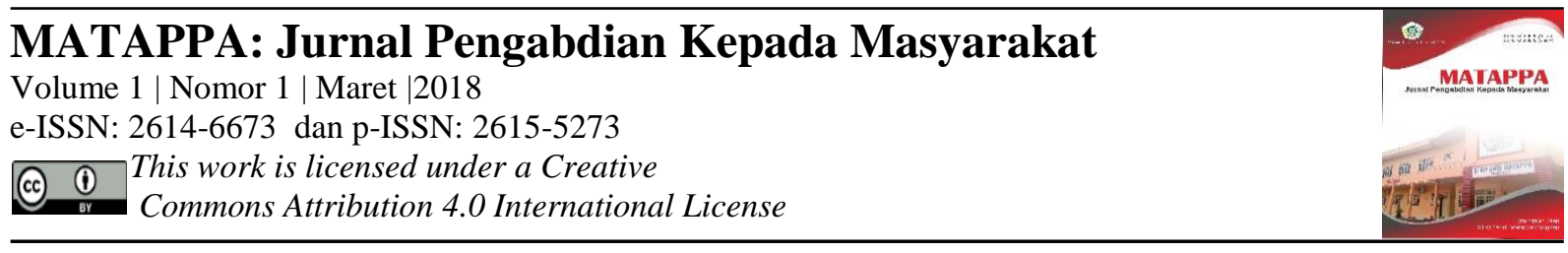

\title{
IbM Bank Sampah Desa Mojorejo Kota Batu
}

\section{Novi Puji Lestari ${ }^{1)}$ Dicky Wisnu Usdek Riyanto ${ }^{2)}$}

\section{Keywords :}

Kata Kunci;Waste

Kata Kunci; managed bank

trash,

Kata Kunci.Waste bank

\section{Corespondensi Author}

${ }^{1)}$ Manajemen Universitas

Muhammadiyah Malang

Perum Junrejo Indah B-18 Junrejo

Email: novipujilestari61@gmail.com

\section{History Artikel}

Received: 14-02-2018

Reviewed: 20-02-2018

Revised: 02-03-2018

Accepted: 15-03-2018

Published: 30-03-2018

\begin{abstract}
ABSTRAK
Populasi dari penelitian ini adalah warga Mojorejo Batu, yang sebagian besar merupakan ibu rumah tangga dan pengusaha kecil yang menghasilkan banyak limbah baik limbah plastik maupun limbah basah setiap harinya. Selama ini pengelolaan sampah warga Mojorejo dibantu oleh warga desa PKK yang berjalan kurang maksimal. Tujuan kegiatan ini adalah untuk membantu warga Mojorejo memanfaatkan limbah plastik menjadi produk yang bisa dijual dan bermanfaat.Kegiatan utama dari program layanan ini adalah mengolah sampah plastik menjadi barang jadi atau daur ulang produk, sehingga bisa meningkatkan pendapatan ibu desa Mojorejo.Metode yang digunakan adalah memberikan pelatihan kepada ibu rumah tangga Mojorejo untuk memanfaatkan sampah plastik menjadi produk yang layak dijual.
\end{abstract}

\section{PENDAHULUAN}

Desa Mojorejo merupakan salah satu desa yang terletak pada wilayah Pemerintah Kota Batu Kabupaten Malang. Desa yang berlokasi dekat dengan pusat Kota Batu ini memiliki banyak manfaat positif yaitu dengan adanya beberapa home industry dan ada kampus agama Budha di daerah ini sehingga menghasilkan pendapatan dan mempunyai dampak negatif yaitu terkait limbah sampah. Dampaknya adalah banyak-nya sampah kertas maupun plastik sebagai akibat kegiatan kampus tersebut dan menumpuk menjadi sampah yang tidak berguna. Selain itu sampah-sampah plastik dari home industry sekitar juga mempunyai efek negatif terhadap lingkungan desa Mojorejo. Sebenarnya adanya sampah itu akan menjadi peluang usaha, menghasilkan dan menyerap tenaga kerja dengan catatan usaha tersebut dikelola dengan manajemen yang baik. Salah satu model pengelolaan sampah adalah dengan bank sampah. Namun harus diperhatikan Bank Sampah yang dikelola dengan adminstrasi yang baik sehingga penabung akan percaya pada usaha tersebut.

Desa Mojorejo selama ini pengelolaan sampah dipercayakan kepada ibu-ibu PKK namun belum maksimal,karena sampah plastik hanya dipilah saja belum difikirkan manfaatnya yang sebenarnya banyak produk yang dihasilkan dari sampah tersebut.

Berdasar uraian di atas masalah mitra kegiatan ini adalah belum adanya pengelolaan sampah yang baik dan terorganisisr yang harusnya bisa menambah penghasilan warga dan PKK desa, termasuk masalah pemilihan pemasok, masalah pemasaran, perhitungan harga beli maupun harga jual. Hal ini dipengaruhi oleh terbatasnya pengetahuan masyarakat dan pengelola dalam manajemen bank sampah. Sebenarnya beberapa anggota PKK yang terdiri dari ibu - ibu di lingkungan RW 03 desa Mojorejo yang kebanyakan adalah 
ibu rumah tangga mereka ada yang mempunyai ide terkait manfaat daur ulang dari sampah, namun minimnya biaya dan belum adanya pelatihan dalam pembuatan produk daur ulang maka ide ini belum dijalanakan. Pengabdian ini difokuskan untuk pelatihan pengelolaan sampah plastik dan sampah kering berupa kertas melalui pengelolaan bank sampah yang dikelola bersama oleh ibu - ibu anggota PKK di lingkungan RW 03 Desa Mojorejo Kota Batu.

Dapat diidentifikasi bahwa
permasalahan mitra adalah: (1) Kesadaran warga desa Mojorejo terkait manfaat lain dari pemilahan sampah. (2) Pengetahuan masyarakat tentang bank sampah belum cukup untuk membuat suatu wadah organisasi atau usaha yang dikelola dengan manajemen yang baik. (3) Belum adanya pelatihan ataupun bantuan administrasi dari pemerintah daerah terkait pengelolaan sampah.

Tujuan kegiatan ini adalah memberikan pelatihan kepada warga sekitar terkait pengelolaan bank sampah dan membentuk organisasi bank sampah yang dikelola dengan manajemen yang baik. Dengan terbentuknya organisasi ini diharapkan dapat menciptakan nilai tambah ekonomis sampah anorganik serta meningkatkan kesejahteraan masyarakat melalui tabungan pada bank sampah.

\section{METODE}

Sebagai upaya menangani perma-salahan sampah ditengah - tengah masyara-kat ini maka solusi yang ditawarkan adalah sebagai berikut: (1). Memberikan sosialisasi kepada masya-rakat melalui kegiatan pertemuan warga yang terdiri dari ibu-ibu anggota kelom-pok PKK tentang permasalahan sampah dan alternatif solusinya. (2). Membentuk organisasi bank sampah di lingkungan RW 03 Desa Mojorejo. (3).Memberikan penyuluhan dan pelatihan tentang adminstrasi bank sampah kepada pengurus usaha bank sampah. (4). Pelatihan kepada warga sekitar terkait pembuatan produk dari sampah plastik dan sampah kering lainnya. (5). Pendampingan secara berkala dalam mengembangkan usaha bank sampah.

Sasaran kegiatan ini adalah warga dan pengurus PKK yang ada di lingkungan RW 03 Desa Mojorejo Kota Wisata Batu. Jumlah Pengurus ada 8 orang,namun yang bisa hadir kisaran 5 orang. Metode kegiatan ini dilakukan dengan berbagai pendekatan yang meliputi: (1). Penyuluhan serta diskusi dengan mitra tentang permasalahan sampah serta alternatif solusinya dilakukan pada waktu yang bersamaan dengan pertemuan rutin anggota PKK satu bulan sekali. Penyuluhan kepada masyarakat ini dilakukan untuk memberi informasi yang akurat tentang manfaat bank sampah dan mekanisme menabung dan memperoleh hasil secara sosial maupun secara ekonomis. (2). Identifikasi sampah yang merupakan prioritas akan dikelola pada periode ini yaitu hanya sampah anorganik berupa kertas dan plastik mengingat sampah jenis ini mudah disimpan dan tidak kotor. (3). Pelatihan administrasi bukubuku penun-jang bank sampah yang terdiri dari buku induk, buku rekening dan buku kas.

\section{HASIL DAN PEMBAHASAN}

\section{a. Gambaran Umum Mitra}

Desa Mojorejo merupakan salah satu desa yang ada di Kota Batu Kabupaten Malang. Desa ini memiliki wilayah yang sangat luas Penduduk Desa Mojorejo terdiri dari 4.393 jiwa dimana jumlah ibu rumah tangga 733 jiwa dan 25\% diantaranya tidak memiliki pekerjaan. Padahal, jumlah sampah yang dihasilkan di desa ini mencapai $150 \mathrm{~kg} / \mathrm{hari}$. Adanya home indutry dan kamous Agama Budha di desa ini mengakibatkan banyak sampah plastik maupun sampah kertas. Jumlah penduduk yang banyak ini juga mengakibatkan konsumsi barang yang besar dan akan berdampak pada sampah. Sampah yang berasal dari rumah tangga maupun sampah dari home industri.

Kegiatan ini difokuskan pada salah satu lingkungan RW 03 Desa Mojorejo Kota Batu. Alasan pemilihan lokasi, karena RW 03 mempunyai jumlah penduduk sekitar 300 orang dan ada beberapa home industry seperti usaha krupuk, kripik tempe, usaha camilan dan beberapa usaha dagang. Hal ini juga yang akan menambah permasalahan sampah disamping sampah dari rumah tangga.

Namun sampai saat ini belum ada suatu cara atau gerakan untuk mencegah dan menangani sampah secara berkelanjutan. Yang dilakukan adalah menangani perma-salahaan sampah sendiri-sendiri atau secara parsial. Sebagai contoh untuk mengelola sampah anorganik, seperti kertas, plastik, kaleng ada yang langsung membuang sampah di tempat 
sampah, ada yang mem-bakarnya, namun juga ada yang dikum-pulkan pada masing-masing RT untuk selan-jutnya dijual ke tukang loak.

\section{b. Jenis sampah dan klasifikasinya}

1). Sampah organik : sampah yang terdiri dari bahan-bahan yang bisa terurai secara alamiah/biologis, seperti sisa makanan dan guguran daun. Sampah jenis ini juga biasa disebut sampah basah.

2). Sampah Anorganik

Sampah anorganik : sampah yang terdiri dari bahan-bahan yang sulit terurai secara biologis. Proses penghancurannya membutuhkan penanganan lebih lanjut di tempat khusus, misalnya plastik, kaleng dan styrofoam. Sampah jenis ini juga biasa disebut sampah kering.

3). Sampah bahan berbahaya dan beracun (B3)

: limbah dari bahan-bahan berbahaya dan beracun seperti limbah rumah sakit, limbah pabrik dan lain-lain.

\section{c. Pemecahan Masalah}

1). Sosialisasi

Sosialisasi dilakukan pada masyarakat RW 03 melalui forum pertemuan kelompok PKK di masing-masing RT yang diikuti oleh ibu-ibu anggota PKK. Materi yang diberikan meliputi: jenis sampah, dampak yang ditimbulkan dari sampah, dan penyadaran untuk meminimalisasi sampah dengan cara menngunakan produk-produk yang ramah lingkungan. Sampah anorganik biasanya berupa kertas, botol plastik, kaleng, dan lain-lain. Cara mendaur ulang sampah organik.

Di Indonesia, meskipun masih secara sederhana atau tradisional, daur ulang limbah organik juga sudah sering dilakukan. Contohnya adalah pemulungan sampah yang berasal dari sampah rumah tangga yang kemudian dijadikan kompos. Daur ulang mempunyai potensi yang besar untuk mengurangi tambahan biaya pengolahan dan tempat pembuangan akhir sampah. Berdasarkan cara pemanfaatannya, limbah organik dapat dimanfaatkan secara langsung maupun melalui daur ulang terlebih dahulu.

Tanpa melalui daur ulang, limbah organik dapat dimanfaatkan secara langsung, misalnya sampah rumah tangga berupa sayuran, daun-daun bekas dapat dijadikan makanan ternak. Melalui daur ulang, limbah organik dapat juga dimanfaatkan. Contohnya adalah pembuatan pupuk kompos, pembuatan biogas, dan pembuatan kertas daur ulang. Berikut adalah uraian singkat tentang ketiga proses tersebut.

a. Pembuatan Pupuk Kompos (Pengomposan atau Composting) Pupuk kompos dibuat dari limbah organik dengan prinsip penguraian bahan-bahan organik menjadi bahan anorganik oleh mikroorganisme melalui fermentasi. Bahannya berupa dedaunan atau sampah rumah tangga yang lain, serta kotoran ternak (sapi, kambing, ayam). Mikroorganisme yang berperan dalam pembuatan kompos dikenal sebagai effective microorganism (EM). EM terdiri atas mikroorganisme aerob dan anaerob. Kedua kelompok jasad renik tersebut bekerja sama menguraikan sampah-sampah organik. Hasil fermentasinya dapat menciptakan kondisi yang mendukung kehadiran jamur pemangsa nematoda (cacing parasit pada akar tanaman). Kompos digunakan dalam sistem pertanian, bersifat ramah lingkungan, dan hasil panen dari tanaman pertanian yang menggunakannya memiliki harga jual yang lebih mahal. Dengan memanfaatkan pupuk organik, di samping menanggulangi limbah, berarti juga menerapkan gaya hidup sehat. Berikut ini proses pengolahan sampah menjadi kompos.

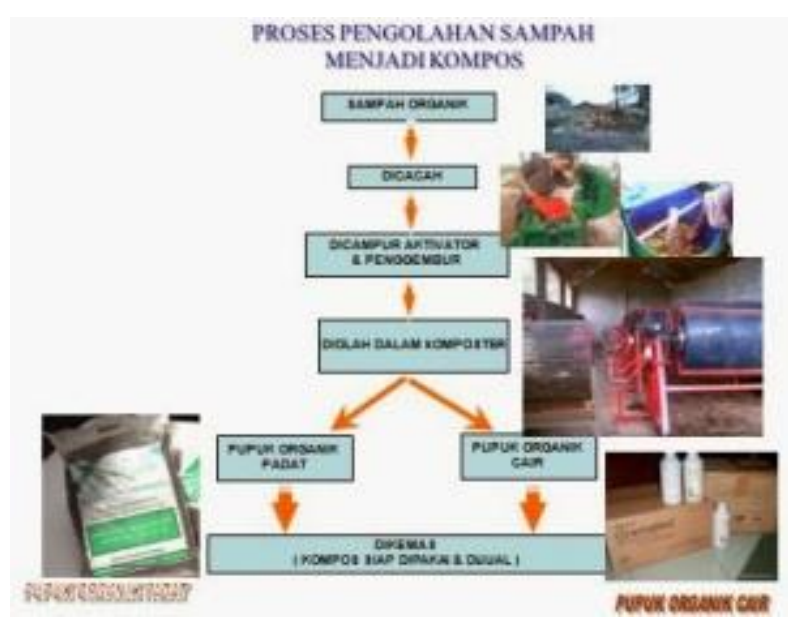

Gambar 1. Pengolahan Sampah menjadi kompos

b. Pembuatan Biogas (Gas Bio) Biogas merupakan gas-gas yang dapat dimanfaatkan sebagai bahan bakar. Gas ini dihasilkan dari proses pembusukan atau fermentasi sampah organik yang terjadi secara anaerobik. Artinya, proses tersebut berlangsung dalam keadaan tertutup (tanpa oksigen), dilakukan oleh bakteri Metalothrypus 
methanica. Bahan bakunya adalah kotoran hewan, sisa-sisa tanaman, atau campuran keduanya. Prosesnya adalah dengan mencampurkan sampah organik dan air, kemudian dicampur dengan bakteri $M$. methanica, dan disimpan di dalam tempat yang kedap udara lantas dibiarkan selama dua minggu.

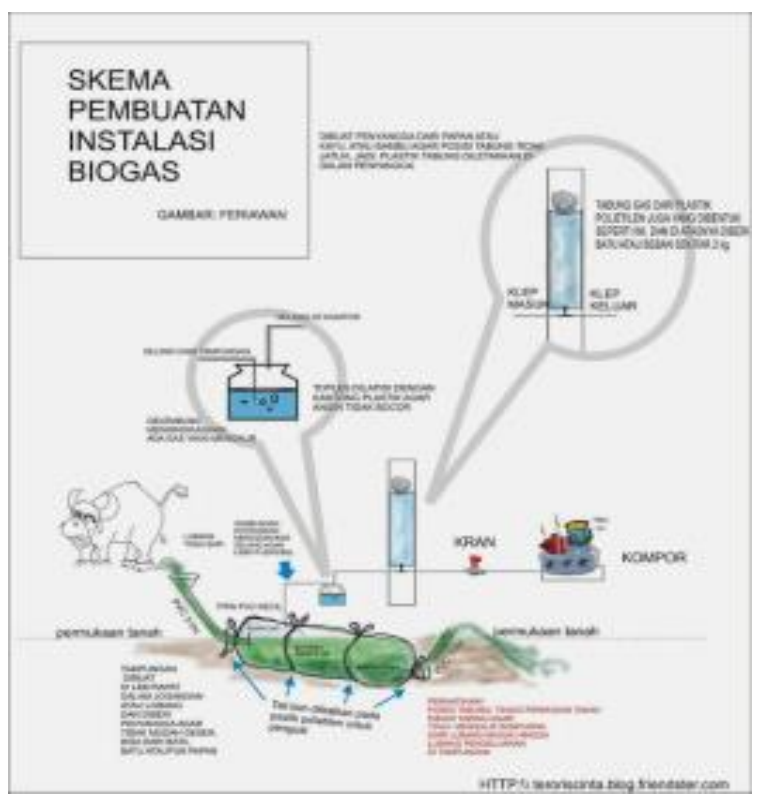

Gambar 2.Skema Pembuatan Biogas

c. Daur Ulang Kertas Daur ulang kertas dari sampah rumah tangga, kegiatan administrasi, kertas pembungkus, maupun media cetak dapat menghasilkan kertas yang dapat dimanfaatkan sebagai kertas buram, kertas pembungkus kado, atau aneka kerajinan yang lain. Berikut cara mendaur ulang kertas.

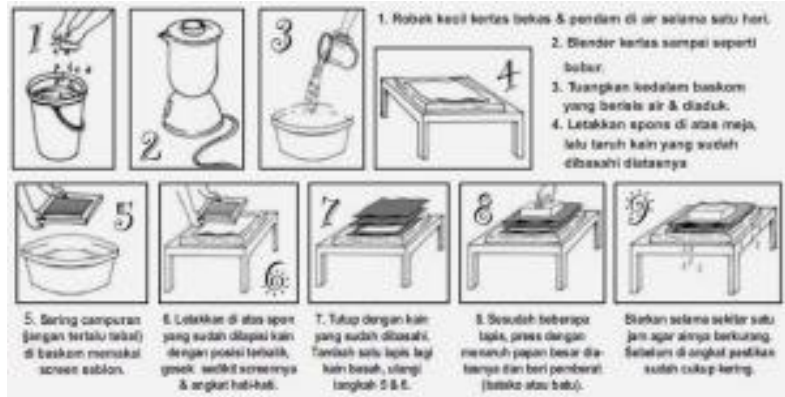

Gambar 3.Daur Ulang Kertas

\section{Daur Ulang Limbah Anorganik}

Limbah anorganik yang dapat didaur ulang yaitu sampah plastik, logam, kaca, plastik, dan kaleng. Limbah tersebut terlebih dahulu diolah melalui sanitary landfill, incineration atau pembakaran, dan pulverisation atau penghancuran. Sanitary landfill yaitu suatu metode pengolahan sampah terkontrol dengan sistem sanitasi yang baik.

Sedangkan pada incineration sampah dibakar di dalam alat yang disebut insinerator. Hasil pembakarannya berupa gas dan residu pembakaran. Sementara itu, pada pulverisation, penghancuran sampah dilakukan di dalam mobil pengumpul sampah yang telah dilengkapi dengan alat pelumat sampah. Sampah-sampah tersebut langsung dihancurkan menjadi potongan-potongan kecil yang dapat dimanfatkan untuk menimbun tanah yang letaknya rendah. Berikut dokumentasi pelatihan:

Hasil Produk dari Pengabdian ini adalah sebagai berikut :

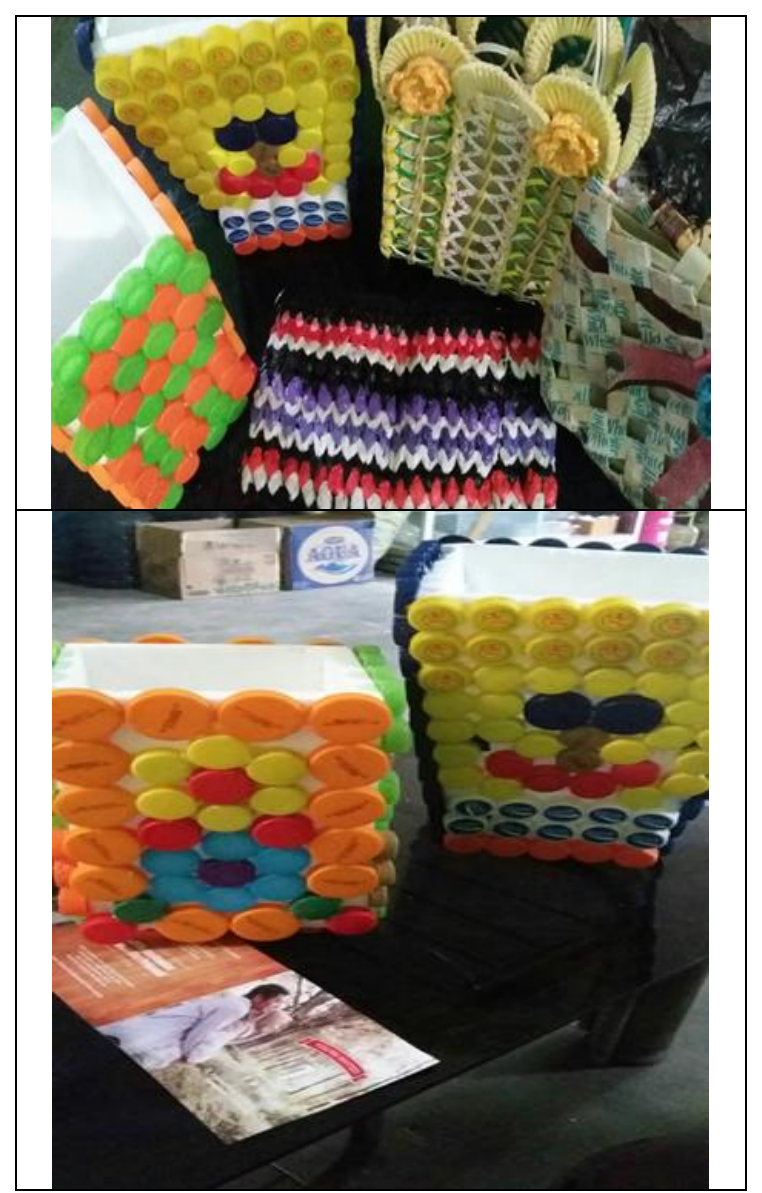




\section{SIMPULAN DAN SARAN}

Berdasar kegiatan dalam pengelolaan sampah di lingkungan RW 03 Desa Mojorejo Kecamatan Junrejo ini dapat disimpulkan bahwa permasalahan sampah adalah tanggung jawab bersama, dimulai dari unsur paling kecil yaitu rumah tangga. Sampah diklasifikasikan menjadi dua(2) jenis yaitu sampah organik dan sampah anorganik. Karena sampah anorganik lebih sulit untuk didaur ulang, maka kegiatan ini difokuskan untuk pengelolaan sampah anorganik, khusus kertas dan plastik.

Selama periode kegiatan, terjadi kendala yaitu waktu untuk pemilahan sampah botol ataupun plastic yang memerlukan waktu lama,serta kendala pada pelaksanaan bank sampah hanya dilakukan satu bulan sekali sehingga saat pelatihan bahan untuk pelatihan stocknya belum ada.

\section{DAFTAR RUJUKAN}

Alma Buchari, (2015). Pengantar Bisnis, Penerbit Alfabeta Bandung.

Hall,James, (2015). Sistem Informasi Akuntansi"Edisi keempat,Salemba Empat Jakarta

Siregar Baldric. (2015) Akuntansi Biaya.Salemba Empat.

Romney \& Steinbart. (2015). Sistem Informasi Akuntansi" Edisi 13,Salemba Empat Jakarta

Scneider \& White. (2004). Service Quality: Research Perspective, Sage Publication Ltd,California 